\title{
The Legislative Process
}

Karen T. Graves

Editor's Note: This article is reprinted with permission from the Medical Library Association News, March 1983.

A new Congress, the First Session of the 98th Congress, convened on January 3, 1983. Legislation affecting librarianship will be considered by this new Congress. ACRL and MLA encourages librarians, individually and in groups, to become involved in the political process. The ability to influence legislation depends, to some extent, on an understanding of the legislative process. The following synopsis of the procedural steps in the legislative process may provide guidance regarding how and when best to become involved. ${ }^{\prime}$

\section{Forms and Designation of Legislativive Business}

All proposed legislation and nearly all formal actions of either House, take the form of a bill or resolution. A bill is a legislative proposal of a general nature. Bills account for the majority of the legislative proposals of each Congress. In each House, bills from each Congress are numbered in sequence starting with number 1 . Thus bill number 100 in the Senate is written S.100 and in the House, H.R.100. It is helpful to use this number when referring to a bill or when requesting a copy of a particular bill.

\section{Origin of Legislation}

Legislation originates in several ways. The President may personally address a joint session of the two Houses, or he may send messages in writing to Congress. The ideas for legislative proposals may come from an individual Senator or Representative, from any of the executive departments of the government, from private groups or associations, or from an individual citizen. However, bills can be introduced only by Senators or Representatives. For example, in the 97th Congress, H.R.6338, a bill to amend the Public Health Service Act (Title Il of this bill authorized appropriations for the $\mathrm{Na}$ tional Library of Medicine) was introduced in the House by Representative Waxman (D-Calif.). Bills are introduced by the primary sponsor. Other members who support the bill may be listed as cosponsors. Sponsors or co-sponsors of a bill may be contacted to obtain information regarding the status of the bill as well as to indicate support for a particular bill.

${ }^{1}$ R.B. Dove, Enactment of a Law: Procedural Steps in the Legislative Process (Washington: Gov't Printing Office, 1982.)

\section{Committee Referral}

The rules require that each bill has three readings before passage with two readings being required before the bill is referred to a committee. This is seldom done now since all bills and resolutions are available in printed form. A bill is referred by the Presiding Officer to the standing committee which in his judgment has jurisdiction over the subject matter of the bill. The Public Health Service bill mentioned earlier was referred to the House Energy and Commerce Committee.

\section{Committee Consideration}

Most of the standing committees have standing subcommittees and the committee may refer pending bills to an appropriate subcommittee. After the Public Health Service bill in the House was refer red to the Committee on Energy and Commerce, the bill was then referred to its Subcommittee on Health and the Environment.

Committees or subcommittees generally hold hearings on all major and/or controversial legislation before drafting the proposal into a final form. The length of the hearing varies depending on such things as the time element, the number of witnesses wishing to be heard and the number of expert witnesses the committee wishes to hear. Private groups or individuals may request to be heard by the committee or may present written testimony for consideration. Individuals may also convey their opinions on a certain bill to the chairman or other members of the committee.

\section{COMMITTEE ACTION}

After consideration of the bill which includes debate and a vote, the subcommittee reports to its full committee. The full committee may adopt the re port without change, amend it, reject it, or adopt an entirely different report. For example, the original H.R.6338 Public Health Service bill was incorporated into other bills and was reported out of the Committee on Energy and Commerce as H.R.6457, with an amendment. Also, committees may choose not to act on every bill referred to them. If committee action is taken, a "mark-up" session is held prior to reporting the bill back to the full House or Senate. At this session the final form and content of the measure is determined.

\section{Committee Reports}

The committee may report the bill to the House or Senate with or without amendments, submit an adverse report on the bill, or vote not to report anything. The action taken by the committee will appear on the copy of the bill. The written committee report, which may include minority, supplemental, or additional views, is printed and accompanies the bill and is available to the public. 
or SENATE

A bill is reported to the Senate by the committee chairman and when reported is placed directly on the Senate Calendar of Business. The majority leader, in consultation with the minority leader and the policy committee, is responsible for directing the legislative schedule as to when bills are considered. Debate is unlimited unless the bill is considered under a unanimous consent agreement limiting debate and controlling time on the measure.

In the House the bill is first sent to the Rules Committee where it is granted a rule. The rule defines how the bill will be considered, by limiting the time for debate and the number of amendments which will be considered. For example, H.R.6457 was granted an open rule with one hour of debate. Several amendments to this bill were offered and voted upon and the final amended bill passed the House by a vote of 365-12.

When a bill passes one House it is then sent to the other House where it goes through the same process of committee referral and consideration. H.R.6457 passed the House and was received in the Senate on September 30, 1982. It was referred to the Senate Committee on Labor and Human Resources on October 1, 1982. On October 19, 1982, this committee requested executive comment from the Health and Human Services Department, the Defense Department, the Education Department, the Veterans Administration, the National Science Foundation, the Government Accounting Office, and the Office of Management and Budget. The Senate Committee on Labor and Human Resources did not complete consideration of this bill by December 24, 1982, and it died due to no action being taken by the Senate.

\section{Conference}

A bill must be passed in the same form by both Houses before it can be sent to the President. If a different form of the bill is passed by each House, conferees are appointed from each House to work out the differences. The conferees usually produce a compromise measure which is acceptable to both Houses. The conference report is first approved by the committee and then the report accompanies the bill back to both Houses.

\section{Final Passage}

Conference reports are privileged in both Houses. They cannot be amended, but must be voted upon as an entirety. After adoption by one House, the conference report is transmitted to the other House for approval. If approved by both Houses, the final version of the bill is first signed by the Speaker of the House and then the VicePresident before it is sent to the President for his signature.
Under the Constitution the President has ten days (Sundays excepted) after the bill is presented to him to act upon it. The President may approve the bill and sign it, and it becomes a law. The President may not approve the bill but be unwilling to veto it directly, so he does nothing and after ten days the bill automatically becomes a law. The President may also pocket veto a bill by not signing the bill within the ten-day period after the final adjournment of the Congress. If the President does not approve a bill and vetoes it, he then returns the bill with his objections to the House of origin.

The Constitution provides for reconsideration by both Houses of a bill which has sustained a Presidential veto. The House of origin acts first and the bill must receive a two-thirds vote in each House to override the veto and become a law.

\section{How You Can Help}

It is not surprising that only a very small percentage of the total number of bills introduced into Congress ever become law. ${ }^{2}$ Individuals can affect legislation in several ways. First, requests for copies of bills and concerns regarding bills should be directed to congressional offices. Congressional staff members are very sensitive to constituent concerns and interests. Also committee members and sponsors of bills should be contacted during the hearing process. Individual representatives and senators should be contacted when the bill comes up before the full Houses for final passage.

Congressional offices will be able to provide information on the status of a particular bill as a service to their constituents. All congressional offices now have access to SCORPIO (Subject Content Oriented Retriever for Processing Information Online) which is a database prepared by the Library of Congress for use by Congress. One of the SCORPIO files provides information on the status of all current legislation. All requests for information concerning a bill will be interpreted by staff members as concern and interest of constituents for that specific legislation. That would be an excellent time to express to staff members specific concerns regarding the legislation.

The ALA, ACRL, and MLA Legislation Committees and the ALA Washington Office will continue to monitor legislation of interest to librarians and continue to provide information when action is appropriate and needed. Individuals can often affect the legislative process and all librarians are urged to begin exercising this prerogative by becoming more familiar with current legislation concerning libraries.

${ }^{2}$ For an interesting description of the process, see Eric Rodman, Dance of Legislation (New York: Simon \& Schuster, 1973.) 


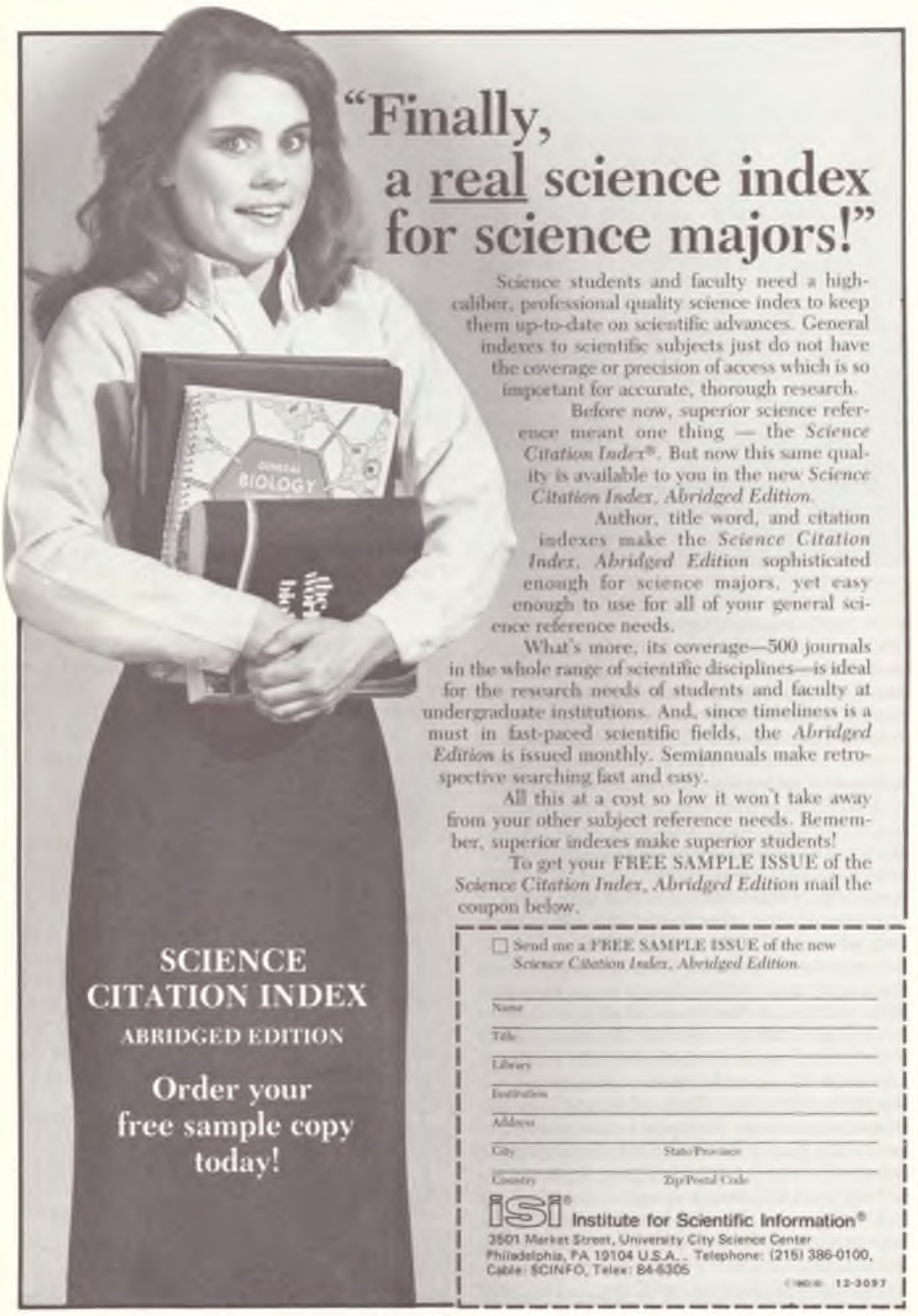

